\title{
ATTEMPTS TO PRODUCE EXPERIMENTAL GASTRITIS
}

\author{
BY FRANCIS D. W. LUKENS
}

(From the Gastro-Intestinal Section of the Medical Clinic, Hospital of the University of Pennsylvania, and the John Herr Musser Department of Research Medicine, University of Pennsylvania, Philadelphia)

(Received for publication October 5, 1932)

The conception of chronic gastritis as the basis for ulcer and cancer of the stomach is an old one which has been the subject of renewed interest as a result of the recent work of Faber (1), Aschoff (2), Konjetzny (3) and others in Europe. They have classified gastritis as endogenous when caused by a blood borne agent, and as exogenous when it is due to the direct action of the causative factor on the gastric mucosa. Such a distinction may be difficult in the clinic; it is perhaps more easily possible in the laboratory. If fairly diffuse, low grade inflammatory changes do form the background for ulcer and cancer, a knowledge of the causation of such alterations is essential to a complete understanding of the resultant clinical conditions. The present work has been undertaken to study the experimental production of exogenous gastritis. The attempt has been made to correlate the pathological picture with the function of the stomach as measured by its ability to secrete hydrochloric acid. The methods have been sufficiently drastic and long continued to justify their description in spite of the negative results.

In 1902 Turck (4) studied the changes occurring within 48 hours after the administration of a solution of mustard oil to dogs with empty stomachs. The feature of the microscopic findings was that the surface epithelium was well preserved although there was congestion with considerable infiltration of leukocytes and lymphocytes in the deeper portions of the mucosa. The lesions were acute in type. No control stomachs were described, although the animals were killed by ether inhalation which may have added to the irritation of the stomach. In 1906 he (5) reviewed briefly some experiments in which suspensions of mustard oil were added to the food of dogs for periods of 9 to 14 months. The animals eventually adapted themselves to taking the irritant and there were no symptoms with the later doses. Although the lesions are not described he reported the development of chronic gastritis. He also reported the appearance of ulcers after feeding cultures of B. coli. Aubertin and Hébert (6) gave rabbits and guinea pigs bread soaked in absinthe. The results were confusing, as some stomachs were normal after 10 months, while others showed changes after 2 months. The 
lesions consisted of hyperplasia of the lining and of the mucous cells and some sclerosis. They say in a footnote that dogs frequently have an advanced gastritis. Foster (7) used dogs with a Pavlov double stomach and mixed alcohol with their food. This produced at first an increase in the amount of juice with later a prompt falling off in the amount and an increase of mucus. There are no details of the method, and no acid determinations or microscopic sections were made.

Bolton (8) gives an excellent review of "exogenous" irritation of the stomach in discussing the experimental attempts to produce ulcer. Minor lesions have been produced by the introduction by mouth or stomach tube of a wide variety of substances such as bacteria, poisons, acids, etc. More recently, Gottschalk (9) studied the changes occurring within 5 days in cats into whose stomachs $20 \mathrm{cc}$. of 60 per cent alcohol had been introduced. These lesions were focal, on the crests of the mucosal folds, the pyloric portion being relatively unaffected. Gotschlich (10) observed very similar changes with focal necrosis after giving cats solutions of 0.8 to 1.5 per cent hydrochloric acid. Both these authors believe that the changes are comparable to the exogenous gastritis which precedes ulcer. Thomsen (11) has studied the changes resulting from the administration of alcohol to dogs with gastric fistulae, and presents the only experimental correlation we have seen between secretory changes and lesions. He found that the quantity of secretion gradually diminished to a marked degree, while the quality as measured by the $\mathrm{pH}$ and pepsin content was maintained to the end. Florey (12), in describing the physiology of the secretion of mucus, refers to the immediate enlargement of the goblet cells of the pylorus following mustard oil. Overgaard (13) described interstitial infiltration and erosive changes in the pyloric portion of the dog's stomach resulting from $(a)$ hydrochloric acid by tube, and $(b)$ hydrochloric acid secreted in response to the daily injection of histamine. The recent report of Bergsma (14) on the high incidence of ulcer in Abyssinians whose diet contains much pepper is of interest in this connection.

\section{METHODS AND RESULTS}

Four healthy male dogs were kept on the usual doghouse diet (table residues with much meat), and given adequate facilities for exercise. They were trained to take a stomach tube without any evidence of fear or discomfort.

Gruel meal tests. After fasting for 16 hours, 75 to $400 \mathrm{cc}$. of gruel (usually $200 \mathrm{cc}$.) were given by tube and the gastric contents recovered one or more times at intervals of 15 minutes to 1 hour. In all, 20 tests were made on the 4 dogs. In 7 of these no part of the test meal was recovered. Of the remaining 13 , only 2 showed free acid, the values being 2 and 8 . A few attempts, all unsuccessful, were made to aspirate 
something after an hour, a time when high acid concentration might have been expected. The conclusion from these 20 tests was that the gruel meal used in man is not a satisfactory stimulus to the dog's stomach.

Histamine tests. One-half cc. of a $1: 1000$ solution of histamine (ergamine diphosphate) was the usual dose given after fasting. In a few preliminary tests the stomach was aspirated every 15 minutes until nothing further could be obtained. In these trials the maximum acidity was generally found a half hour after the injection of histamine. The figures reported were commonly obtained at this interval. These free acid figures fell in 3 animals within a wide but fairly consistent range of approximately 20 to $80 \mathrm{cc}$. N/10 per cent. In the fourth animal mucus was usually present in large amounts and the acid figures were low with occasional high figures. The three dogs with a consistent range of acid figures, as based on 21 or more histamine tests for each animal, were considered ready for the attempts to produce pathological changes. The efficacy of this method of gastric analysis is indicated by the fact that in 110 tests sufficient juice for analysis was obtained in 94, while in 16 no stomach contents were obtained during the hour following histamine.

Meat broth as test meal. A few tests were made to determine the efficacy of meat broth as a test meal. Beef infusion broth (media) was used, the usual amount being $200 \mathrm{cc}$., and it was taken voluntarily by the dogs. The stomach contents were aspirated every 15 minutes and examined for acid in the usual way. A total of 19 broth meals was given to 3 dogs. Seven of the tests showed no free acid, while 12 gave satisfactory values of free acid ranging from 8 to 48 , and of total acid from 20 to 98 . The test, like histamine, was more successful in some animals than in others. The results were a distinct contrast to those of the gruel meals. They were comparable to those obtained after histamine except that the free acid figures were slightly lower and appeared at a longer interval after stimulus.

\section{A. Attempts to irritate the empty stomach}

Mustard oil (synthetic) was given to fasting dogs by tube in strengths of $1: 1000$ at first and later $1: 500$ in aqueous solution. (See Table 1.) Three dogs had each 11 doses of $25 \mathrm{cc}$. of $1: 1000$ mustard oil within a period of 16 days. In all but three or four instances there was prompt vomiting and no later symptoms of gastric distress. Similar doses of mustard oil were given in concentration of $1: 500$. The dosage, time intervals and number of doses retained are shown in the table in which the total work with mustard oil is given. The difference in dilution was without distinctive effect. No symptoms and no changes in acidity appeared. 
TABLE 1

Procedures used to irritate fasting stomach

\begin{tabular}{|c|c|c|c|c|}
\hline Procedure & 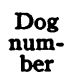 & $\begin{array}{c}\text { Number } \\
\text { of } \\
\text { doses }\end{array}$ & $\begin{array}{l}\text { Period } \\
\text { in } \\
\text { days }\end{array}$ & $\begin{array}{l}\text { Number } \\
\text { of doses } \\
\text { retained }\end{array}$ \\
\hline $\begin{array}{l}\text { Mustard oil, } 20 \text { to } 25 \mathrm{cc} \text {. Both } 1: 1000 \\
\text { and } 1: 500 \text { dilution }\end{array}$ & $\begin{array}{l}467 \\
505 \\
512 \\
514\end{array}$ & $\begin{array}{l}17 \\
18 \\
18 \\
11\end{array}$ & $\begin{array}{l}30 \\
30 \\
31 \\
31\end{array}$ & $\begin{array}{l}2 \\
6 \\
3 \\
1\end{array}$ \\
\hline Average per animal $\ldots \ldots \ldots \ldots \ldots$ & & 16 & 30.5 & 3 \\
\hline Tincture of capsicum, 5 to $10 \mathrm{cc}$. & $\begin{array}{l}505 \\
512\end{array}$ & $\begin{array}{l}19 \\
15\end{array}$ & $\begin{array}{l}47 \\
29\end{array}$ & $\begin{array}{l}16 \\
11\end{array}$ \\
\hline Average per animal $\ldots \ldots \ldots \ldots$ & & 17 & 35.5 & 13.5 \\
\hline Water at 50 to $70^{\circ} \mathrm{C} ., 200 \mathrm{cc}$. & $\begin{array}{l}467 \\
514\end{array}$ & $\begin{array}{l}23 \\
21\end{array}$ & $\begin{array}{l}57 \\
48\end{array}$ & $\begin{array}{l}14 \\
11\end{array}$ \\
\hline Average per animal $\ldots \ldots \ldots \ldots$ & & 22 & 52.5 & 12.5 \\
\hline
\end{tabular}

In attempting to irritate the stomach by tincture of capsicum, the drug was given by tube in doses of 5 or $10 \mathrm{cc}$. to two fasting dogs as shown in Table 1. The difference in the number of doses retained, as compared to mustard oil, is striking. No symptoms and no acid changes were noted during this experiment.

Two dogs which had previously been used in the mustard experiments were given $200 \mathrm{cc}$. of hot water by tube on an empty stomach over a series of days. The temperature of the water was from 50 to $71^{\circ} \mathrm{C}$. Like the capsicum, hot water was fairly well retained. The production of symptoms was irregular and they were always transitory. Table 1 shows the number and character of the experiments.

The foregoing experiments include a small number in which an effort was made to diminish the incidence of emesis. On three occasions the mustard oil was given two hours after one quarter grain of morphine, and one of these doses was retained. In the case of capsicum, all of 11 doses which followed morphine were retained, and after morphine only 1 of 14 doses of hot water (all above $60^{\circ} \mathrm{C}$.) was vomited. Mustard oil given about 20 minutes after $50 \mathrm{cc}$. of 1 per cent novocaine had been put in the stomach was retained in only 1 of 8 trials. Turck (4) found local anesthesia ineffective and used general ether anesthesia in some of his acute mustard oil experiments. Using both local and central emetics, Leake (15) has shown that morphine first irritates and then depresses the vomiting center in the dog. 
TABLE 2

Gastric analyses (less than 8 observations per group)

\begin{tabular}{|c|c|c|c|c|}
\hline Stimulus & $\underset{\substack{\text { num- } \\
\text { ber }}}{\text { Dog }}$ & $\underset{\substack{\text { Time after } \\
\text { stimulus in } \\
\text { minutes }}}{ }$ & $\begin{array}{l}\text { Free } \mathrm{HCl} \\
\text { cc. N/10 per } 100 \mathrm{cc} .\end{array}$ & $\begin{array}{l}\text { Total acid } \\
\text { cc. N/10 per } 100 \text { cc. }\end{array}$ \\
\hline \multicolumn{5}{|c|}{ Control period } \\
\hline \multirow[t]{4}{*}{ Gruel } & 514 & $\begin{array}{l}15 \\
30 \\
45 \\
60\end{array}$ & $\begin{array}{l}0,0 \\
0,0,0,0 \\
0,0 \\
0\end{array}$ & $\begin{array}{l}6,8 \\
4,16,4,4 \\
4,4 \\
4\end{array}$ \\
\hline & 505 & 30 & $0,0,0,0$ & $4,4,10,8$ \\
\hline & 512 & $\begin{array}{l}15 \\
30 \\
45 \\
60\end{array}$ & $\begin{array}{l}0 \\
0,0 \\
6 \\
8\end{array}$ & $\begin{array}{l}30 \\
10,16 \\
22 \\
28\end{array}$ \\
\hline & 467 & $\begin{array}{l}30 \\
45\end{array}$ & $\begin{array}{l}2,0,0 \\
0\end{array}$ & $\begin{array}{l}16,32,6 \\
10\end{array}$ \\
\hline \multirow[t]{3}{*}{ Broth } & 514 & $\begin{array}{l}15 \\
30 \\
45 \\
60 \\
75 \\
90\end{array}$ & $\begin{array}{l}0 \\
12,0 \\
0,0,0 \\
0,0,0,0 \\
30,0,0 \\
0\end{array}$ & $\begin{array}{l}12 \\
46,10 \\
10,10,20 \\
10,6,6,6 \\
44,4,6 \\
4\end{array}$ \\
\hline & 505 & $\begin{array}{r}15 \\
30 \\
45 \\
60 \\
75 \\
90 \\
120\end{array}$ & $\begin{array}{l}0,0 \\
0,0,0,0,0,0,0 \\
26,0,0,0,0 \\
48,0,14,0,0 \\
46,20,22,8,18,8 \\
32,32 \\
38\end{array}$ & $\begin{array}{l}24,10 \\
36,30,20,8,22,28,22 \\
80,14,30,24,34 \\
90,16,34,36,26 \\
80,48,44,34,46,44 \\
60,66 \\
68\end{array}$ \\
\hline & 512 & $\begin{array}{l}15 \\
30 \\
45\end{array}$ & $\begin{array}{l}0,0 \\
40,0,0,0,0 \\
52,20\end{array}$ & $\begin{array}{l}16,18 \\
76,28,32,40,32 \\
98,40\end{array}$ \\
\hline Histamine & 514 & 45 & $34,6,10,36,0,0$ & $50,16,22,44,4,4$ \\
\hline \multicolumn{5}{|c|}{ Experimental period } \\
\hline \multirow[t]{2}{*}{ Histamine } & 505 & 30 & $\left\{\begin{array}{l}44,48,64,56 \\
30,34,16\end{array}\right.$ & $\begin{array}{l}60,72,84,68 \\
64,50,26\end{array}$ \\
\hline & 512 & 30 & $4,60,32$ & $12,74,60$ \\
\hline
\end{tabular}

Tables 2 and 3 give the results of the gastric analyses with respect to free $\mathrm{HCl}$ and total acid in 123 test responses on the four dogs, 98 of these test responses being during the control period. In addition to the observations recorded it has already been noted that especially after the gruel meal it often was impossible to recover any contents from the 


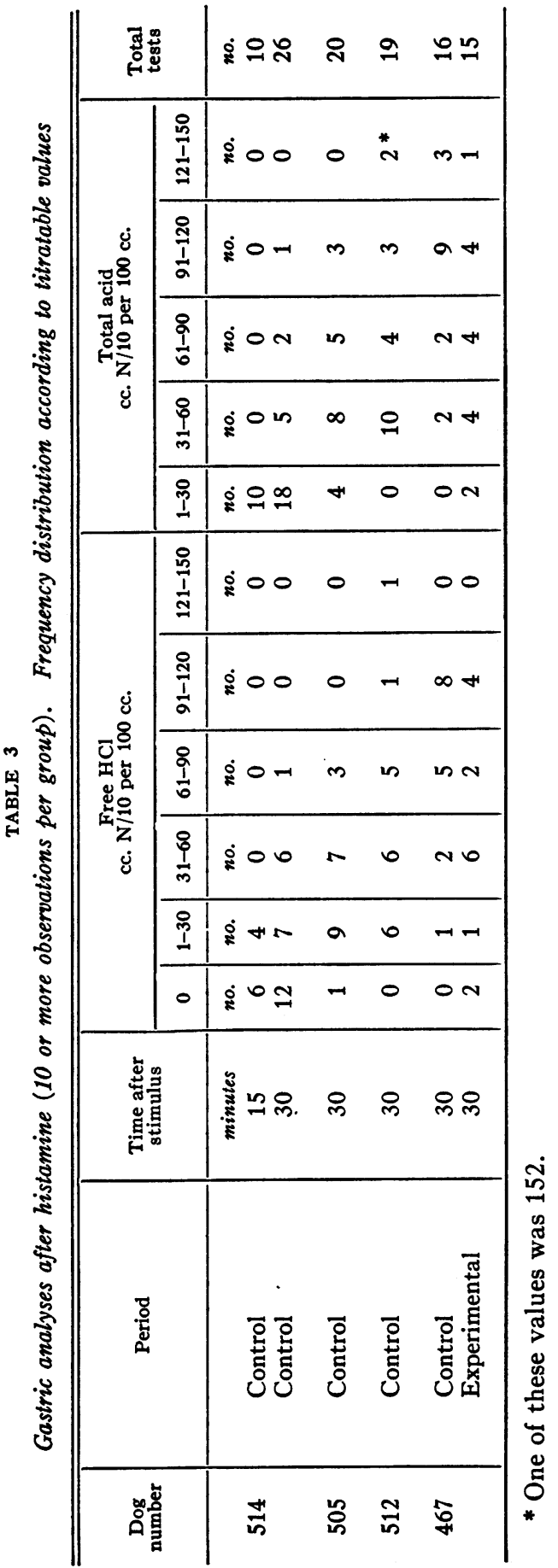


stomach. The scattered observations are detailed in Table 2. The larger groups of observations are summarized in Table 3.

The inferiority of gruel and of broth for our purposes is indicated from a comparison of the data in the two tables. The wide variation in response in the same animal to the same stimulus as well as the difference in response from animal to animal is evident especially in Table 3 . The observations during the experimental period are not clearly significantly different from those during the control period.

Biopsies and autopsies were performed as shown in the following protocols.

\section{PROTOCOLS}

Dog number 512. February 12th to March 20th, 26 histamine tests; March 21st to April 21st, 18 doses of mustard oil; April 25th to May 26th, 9 broth test meals; May 27th to July 19th, 15 doses of tincture of capsicum.

In this and all other animals only the transitory symptoms of nausea and vomiting were observed. The free acid figures varied widely in this animal but did not appear altered by the experiment.

Biopsy was done on July 21st. Grossly the stomach and duodenum were normal in appearance. Microscopic examination showed some large lymphoid follicles in the fundus, which was otherwise within normal limits. The pylorus was not resected.

Autopsy three months later revealed no gross lesions except the completely healed scar of the biopsy, and this was composed of a minimal amount of connective tissue. No microscopic sections were made. In conclusion, the findings were negligible.

Dog number 514. February 21st to April 8th, 34 histamine tests; April 9th to May 10th, 11 doses of mustard oil; May 2nd to June 5th, 5 broth test meals; May 24th to July 11 th, 21 doses of hot water.

Biopsy on July 16th disclosed a grossly normal stomach and duodenum. Microscopic sections showed slight submucous congestion and one focal area of atrophy of the mucosa. The pylorus appeared normal.

Autopsy was performed three months later. The stomach was grossly normal except for the scars of the biopsies which were healed with only a small amount of connective tissue. Silk sutures were found protruding into the gastric lumen from the mucous membrane. Microscopic sections of fundus and pylorus appeared normal.

Dog number 505. February 17th to March 20th, 26 histamine tests; March 21st to April 21st, 18 doses of mustard oil; April 25th to May 30th, 10 broth test meals; June $2 \mathrm{~d}$ to July 19 th, 19 doses of tincture of capsicum.

Biopsy was done on July 21st. Appearance at operation and sections of fundus and pylorus were normal.

Autopsy three months later showed a well healed scar in the fundus in spite of silk sutures protruding into the lumen. The pyloric scar was healed over the sutures. No other changes were found in the stomach or duodenum. Microscopic examination of the fundus revealed no lesions.

Dog number 467. February 21st to March 21st, 24 histamine tests; March 24th to April 21st, 16 doses of mustard oil; April 25th to June 22d, 23 doses of hot water.

Biopsy June 24th was grossly normal. The animal did not react well from the operation and autopsy was done on June 25th. Microscopic sections 
showed slight edema of the mucosa of the fundus, normal pylorus and in the duodenum slight infiltrative swelling of the tips of the villi. In conclusion, the findings were considered negligible.

\section{B. Experiments with capsicum mixed with food}

The foregoing studies suggested that tincture of capsicum was the best retained of the irritants used. Because the powers of defense of the empty stomach were so great, it seemed advisable to modify the method and give this substance over a long period of time and with food to insure or promote its retention. The possibility of irritating the stomach with capsicum was not excluded by the acute experiments described, and the few positive reports on experimental exogenous gastritis have resulted from methods similar to the following.

TABLE 4

Administration of capsicum with food

\begin{tabular}{|c|c|c|c|c|}
\hline $\begin{array}{c}\text { Dog } \\
\text { number }\end{array}$ & \multicolumn{2}{|c|}{$\begin{array}{l}\text { Average* daily dose of tincture of } \\
\text { capsicum each month }\end{array}$} & Free $\mathrm{HCl}$ in gastric juice & Weight \\
\hline 304 & $\begin{array}{l}\text { November } \\
\text { December } \\
\text { January } \\
\text { February } \\
\text { March } \\
\text { April } \\
\text { May } \dagger\end{array}$ & $\begin{array}{l}c c . \\
10 \\
20 \\
15 \\
20 \\
30 \\
35 \\
35\end{array}$ & $\begin{array}{l}c c . N / 10 \text { per } 100 c c . \\
36 \ddagger \\
86 \\
48,0,28 \\
74 \\
30 \\
72,18,54,86 \\
26,48\end{array}$ & $\begin{array}{l}\text { kilos } \\
11.2\end{array}$ \\
\hline 376 & $\begin{array}{l}\text { November } \\
\text { December } \\
\text { January } \\
\text { February } \\
\text { March } \\
\text { April } \\
\text { May } \dagger\end{array}$ & $\begin{array}{l}10 \\
18 \\
18 \\
22 \\
32 \\
32 \\
30\end{array}$ & $\begin{array}{l}20, \ddagger 92 \\
28,52 \\
96 \\
0 \\
14,34,36,18 \\
28,40\end{array}$ & $\begin{array}{l}12.2 \\
13.2 \\
14.0\end{array}$ \\
\hline
\end{tabular}

* See text.

$\dagger$ Experiment ended May 10th.

$\ddagger$ Before beginning administration of capsicum.

Two new dogs were trained to take a stomach tube, and their gastric acidity was determined by the histamine method. They received tincture of capsicum in increasing doses for six months. Except for transient illnesses of one to two days' duration, both animals remained lively and in excellent health throughout the experimental period, and except for such occasional days, all of the food and with it all of the capsicum was readily eaten. The dosage of capsicum began at $5.0 \mathrm{cc}$. and for the last month was $40 \mathrm{cc}$. daily, except Sundays. This was poured over and well mixed with the food. The partially eaten doses 
have been deducted, while Sundays or days when they did not eat have been included in making up the average daily dosage shown in Table 4, so that the calculated average dosage is below that used on the days they took the drug.

Determination of the gastric acidity was made at intervals during the six months, and the figures for free acid have been shown. The amount of acid and its wide range agree with the findings in normal dogs. It is apparent that there is no effect of the capsicum on the secretion of acid after histamine. Total acid figures parallel those for free acid in the usual manner. The food was "wolfed" with canine enthusiasm, and no nausea, vomiting or diarrhea developed. The stools were slightly more yellow in color but this was not distinctive.

After the animals had been receiving $40 \mathrm{cc}$. of the tincture daily for over two weeks, a routine urinalysis was made on each dog. One had a trace of albumin and occasional hyaline casts; the other had no urinary abnormalities. The urine of both dogs was also tested for capsicum by extraction and tasting as described later. Capsicum was not clearly demonstrable.

The results of the autopsies on both dogs were briefly as follows. The animals were killed by intracardiac injection of ether 24 hours after the last dose of capsicum (46 cc.). Externally the stomachs and duodenums were grossly normal. When opened, one stomach was entirely empty (dog 376), the other (dog 304) contained a few coarse food particles. In each instance the fundus appeared entirely normal in color and consistency, and no evidence of congestion, thickening or ulceration was found. The pyloric portion was very well defined and whiter in color than the fundus, but at the time this difference was not thought to exceed normal limits. No thickening or ulceration was found. In the duodenum there were a few (2 to 3 ) small, very superficial ulcers or erosions with no bleeding or induration. The small intestines contained a moderate number of living round worms, but otherwise no abnormalities were found, and the colon appeared unaltered. In the small intestines the chyme in some places was pale yellow, in others a deep yellow color, perhaps to be attributed to capsicum.

The other viscera showed no abnormalities except for multiple angiomatous cysts of the spleen in one animal (dog 304).

The microscopic sections after comparison with those from a number of control animals showed the following:

The fundus in both cases was normal. Chief and parietal cells were present in the usual numbers. The mucosa and submucosa were of average dimensions and appearance.

In the pylorus the cells of the lining mucosa resembled the largest cells seen in a series of control stomachs. The basal glands were not appreciably different from the normal. There was a slight increase in amount 
and density of the connective tissue underlying the mucosa. This is especially marked near the mucosal surface and does not involve the stroma of the basal glands to any extent. In one case (dog 376) there was an increased number of plasma cells and eosinophiles scattered throughout the submucosa; in the other (dog 304) only a few plasma cells were observed. In dog 376 there were also a few small foci of necrosis and small masses of material in the bottom of several ducts, but these findings are probably unimportant. In brief, the antra present no clearly abnormal appearances and no signs of inflammation.

In both dogs the duodenum showed surface erosions with no inflammatory reaction. There were no true ulcers. The lining epithelium was swollen and hypertrophied, with some vacuolated and goblet cells. In one animal mitoses of these cells were seen. The occasional lymphoid follicles were somewhat larger than normal and there was an increase in the connective tissue and lymphoid cells beneath the surface epithelium. The changes were of the type seen in the pylorus and were insignificant.

No lesions were found throughout the small or large intestines. In both dogs a number of living round worms were present in the jejunum. The heart, lungs, liver and kidney were without significant lesions on microscopic examination. The absence of any anatomical evidence of the absorption of the capsicum was confirmed by the failure to demonstrate capsicum in the liver and kidney. A weighed amount of the organ tested was finely ground and extracted with ether. The ether extract was evaporated, the residue dissolved in alcohol and tasted by several people. There was no burning taste of capsicum which is said to occur if the oleoresin is present in as little as $1: 100,000$ dilution.

\section{DISCUSSION}

The problem of directly irritating a viscus which has such powerful defenses as vomiting and the secretion of mucus is naturally difficult. Antiemetics are only mildly effective, and when effective there still remains the protective action of the mucus. If the irritant is given with food it is diluted. Although the methods of testing are crude it may be inferred that capsicum is not stored in the body in appreciable amounts. Capsicum given as the tincture is contained in 85 per cent alcohol and no control of similar doses of alcohol over the same period of time has been included. This combination of capsicum and alcohol caused no lesions, did not alter the well being of the animal, and the acidity of the gastric secretion was essentially unimpaired. The quantity could not be consistently or accurately measured by this method.

In spite of these difficulties it seemed remarkable that several times the dose of capsicum which is emetic in the empty stomach failed to cause symptoms. The following additional explanations are offered. Although it can be used as a vesicant, capsicum acts primarily on the 
sensory nerve endings, so that it may be tasted in $1: 100,000$ dilution, and yet not be proportionally irritating to the tissues in general. For comparison it may be recalled that strychnine which is tasted in similar dilution has no irritant action. Capsicum applied to the eye or subcutaneously causes intense pain and congestion but little inflammatory reaction. In view of the area of the gastric rugae it is doubtful if the maximum dose employed (40 cc. of the tincture = approximately 4.8 grams of the oleoresin) was as concentrated as that of emplastrum capsici by which 0.25 gram of the oleoresin is applied to each $15 \mathrm{sq} . \mathrm{cm}$. of skin. The maximum dose of capsicum was given with about $500 \mathrm{cc}$. of food and so had an estimated concentration of oleoresin of $1: 100$. Finally, one should remember that the average dog's stomach may contain bone splinters, hair, and all sorts of mechanical "irritants" which cause no symptoms.

\section{SUMMARY}

A comparison of the gruel meal, meat broth meal, and histamine as stimuli of gastric acidity has been made on 4 dogs. The gruel meal did not afford an adequate stimulus for the secretion of free hydrochloric acid in the dog. In this respect its action differed from that of meat broth and of histamine. The same animals were given by stomach tube courses of dilute mustard oil, tincture of capsicum, or hot water. These irritants were administered on an empty stomach; they were poorly retained; and no lesions or disturbances of gastric acidity were demonstrable after these procedures. In two more animals tincture of capsicum was added to the food in increasing amounts for a period of 6 months and was well retained. Although almost 80 times the pharmacopeial dose was attained, no evidence of gastritis could be found in the gastric acidity or at autopsy.

\section{BIBLIOGRAPHY}

1. Faber, K., Lancet, 1927, ii, 901. Chronic Gastritis; Its Relation to Achylia and Ulcer.

2. Aschoff, L., Med. Klin., 1928, xxiv, 1931. Über die peptischen Schädigungen des Magendarmkanals.

3. Konjetzny, G. E., and Puhl, H., Med. Klin., 1927, xxiii, 986, 1025 and 1063. Über die Bedeutung der Gastritis und Duodenitis für die Entstehung des Magen- und Duodenalgeschwürs.

4. Turck, F. B., N. Y. Med. J., 1902, lxxvi, 709. Experimental Gastritis; Early Pathological Changes.

5. Turck, F. B., J. A. M. A., 1906, xlvi, 1753. Ulcer of the Stomach: Pathogenesis and Pathology.

6. Aubertin, C., and Hébert, P., Arch. de mal. de l'appar. digest., 1907, i, 737. Sur le processus histologique de la gastrite alcoolique expérimentale.

7. Foster, N. B., Med. J. and Rec., 1910, 1xxviii, 275. Further Observations on Alcoholic Gastritis and Its Relation to Experimental Gastritis in Animals. 
8. Bolton, C., Ulcer of the Stomach. Edward Arnold, London, 1913, pp. 61-73.

9. Gottschalk, A., Beitr. z. path. Anat. u. z. allg. Path., 1930, lxxxiv, 131. Experimentelle Untersuchungen über die Frühstadien der akuten exogenen gastritis (Alkoholgastritis).

10. Gotschlich, E., Beitr. z. path. Anat. u. z. allg. Path., 1930, lxxxiv, 632. Histologie der experimentellen akuten Ätzgastritis durch verdünnte Salzsäure.

11. Thomsen, E., Acta med. Scandinav., 1925, 1xi, 522. Etudes sur l'achylie neurogène et cellulaire.

12. Florey, H., and Webb, R. A., Brit. J. Exper. Path., 1931, xii, 286. Mucous Secretion in Acute Experimental Inflammation of the Colon and Other Mucous Membranes of the Cat; Histological Changes.

13. Overgaard, K., Acta med. Scandinav., 1931, lxxvi, 273. Experimental Pyloric Gastritis by Dogs.

14. Bergsma, S., Arch. Int. Med., 1931, xlvii, 144. Gastric and Duodenal Ulcer in the Black People of Abyssinia.

15. Leake, C. D., J. Pharm. and Exper. Therap., 1922, xx, 359. The Action of Morphine on the Vomiting Center in the Dog. 